\begin{tabular}{l|c|c|}
\hline DE & DE GRUYTER \\
$\mathrm{G}$ & EPEN & ECONOMIC THEMES (2017) 55(2): 281-304 \\
\hline
\end{tabular}

\title{
APPLYING THE MOODLE PLATFORM IN ONLINE STUDENT SELF-ASSESSMENT
}

\section{Jovica Stanković}

University of Nis, Faculty of Economics, Republic of Serbia

$\bowtie$ jovica.stankovic@eknfak.ni.ac.rs

\section{Slavoljub Milovanović}

University of Nis, Faculty of Economics, Republic of Serbia

$\bowtie$ smilovan@eknfak.ni.ac.rs

\section{Ognjen Radović}

University of Nis, Faculty of Economics, Republic of Serbia

凶ognjen.radovic@eknfak.ni.ac.rs

UDC

004.738.5:3

$78.147(497$.

11)

Original

scientific

paper
Received: 20.03.2017. Accepted: 15.06.2017.
Abstract: Taking into consideration the importance of information and communications technology in higher education both as part of the teaching and grading process, but also the limitations in its application in higher education in the Republic of Serbia, this paper outlines the possibilities which the Moodle platform offers for the definition and use of online self-assessment tests and quizzes in the preparation and simulation of the entrance exam for the Faculty of Economics of the University of Niš. To indicate the importance of egrading for the increase in the effectiveness of learning, the paper analyses the number of created accounts and the number of visits, while a statistical analysis of the candidates' results on the simulated entrance exam, from 2014 to 2016, was used to test the hypothesis on the significance of formative assessment for effective learning. The obtained $t$-test results indicate that formative assessment in this specific instance contributes to the improvement of the candidates' learning process and that the application of such a means of student self-assessment in other areas of study would significantly contribute to the increase in the effectiveness of learning. On the other hand, statistical analyses of individual responses to questions represent a significant source of feedback for teachers, which can be used for the purpose of redefining tests.

Keywords Moodle platform, formative assessment, online selfassessment, higher education.

JEL classification: I20, A20 


\section{Introduction}

E-learning, in the broadest sense, includes teaching with the help of information and communications technology (ICT). In modern conditions e-learning includes the use of wireless and mobile technologies, as well as virtual worlds (Willems, 2011).

The development and widely increasing application of e-learning leads to a more extensive use of the Learning Management Systems - LMSs. The use of these systems has resulted in the need to monitor LMS users' behaviour patterns, to continually improve the teaching process.

Virtual learning environments in the form of a learning management system are increasingly more present at universities and offer various possibilities for blended learning, but also for the realisation of the entire education process online and for facilitating life-long learning (Zorrilla et al., 2010). These systems have been recognised as good pedagogical support for most student activities, allowing students to perform them with less effort, time and money, and restricted access control (Lee \& Choi, 2011).

LMSs offer numerous possibilities for working with students - various activities with the possibility of collaboration and evaluation of acquired knowledge through online electronics tests. Numerous commercial systems have been set up to manage learning, such as Edmondo, Blackboard, SuccessFactors, SkillSoft etc., but there are also free and OpenSource systems available. One of the most frequently used free systems is Moodle (Modular Object-Oriented Dynamic Learning) which is currently being implemented in more than 70000 institutions and has almost 90 million registered users. (Top LMS Software, http://www.capterra.com/learning-management-system-software/\#infographic).

The number of registered Moodle sites in the Republic of Serbia is 371, 243 of which are registered as personal websites (https://moodle.net/sites/ index.php?country=RS). The Moodle platform is the most frequently used platform in higher education institutions in the Republic of Serbia. The research carried out by Bulatović et al. (2013) on a sample of 54 accredited faculties of the various universities of the Republic of Serbia has indicated that in $94,44 \%$ of the cases an LMS which is based on Moodle was implemented. A detailed analysis carried out in several universities has indicated the greatest extent of LMS implementation is to be found among the various faculties of the University of Novi Sad (50\% faculties), then at the faculties of the University of Kragujevac ( $40 \%$ faculties), while $37,5 \%$ of the faculties of the University of Niš and 33,3\% of the faculties of the University of Belgrade implement some form of the LMS. The greatest LMS implementation was noted in the field of medicine (66\% of the cases), while in the humanities it is present at a rate of $38,9 \%$ of the cases. In all the other scientific fields its application is much smaller. Even though e-learning at the faculties of the 
Republic of Serbia began back in 2000 (Milićević et al., 2014), the Faculty of Economics of the University of Niš is in the experimental phase of the Moodle system implementation with the aim of providing support for the candidates wishing to enroll at the faculty through a simulation of the entrance exam.

Learning management systems, in addition to numerous possibilities also have the possibility of monitoring and analysis of user activity. Administrators receive reports on the user activity both at the level of the entire system, but also at the level of individual courses. This option is also available to teachers who provide online courses, which greatly facilitates the monitoring of students' progress and their grading. The choice of techniques and suitable grading tools is a very important component in the process of e-learning. Most LMSs offer the option of developing and processing online tests and quizzes. Such tests can be used for selfassessment which allows the user to follow his own progress and check his/her acquired knowledge. If all the necessary conditions are provided, first and foremost those related to the control of the testing process, the test results can also be used to assess students. At the same time, they differ in terms of whether they provide formative or summative assessment.

The aim of formative assessment is to follow the process of student learning and to offer information based on which teachers could improve their lectures, and students learn the required material. Thus, the students can see what is lacking in their knowledge in fields which require more attention, that is, it is possible to evaluate the students' previously acquired knowledge prior to their attending a particular course. This is usually realised by applying tests of no formal importance for the assessment itself, which can be done at the very beginning, during and after attending a particular course to determine the progress of the students and their understanding of the course material. By monitoring the results of formative assessment, teachers can identify the parts of the material which are more difficult to learn, as well as any questions that students usually misunderstand, based on which they can change both their lectures and the questions they use in their assessment tests. On the other hand, the aim of any summative assessment is to formally check the level of students' knowledge and compare it to the required level, based on which the final grade is determined.

Thus, we can conclude that formative assessment is actually assessment for learning, while sumamative assessment can be considered assessment of learning.

Using ICT in the student assessment is drastically increasing, both in formative assessment and in summative assessment (Bull \& Dalziel, 2003; Kulkarni et al., 2013; Bälter, Enström, \& Klingenberg, 2013). However, like in conventional higher education, the role of formative assessment is small despite its potential for the improvement of the learning and teaching process, while the focus is still on summative assessment (Jenkins, 2005; Pachler et al., 2010; Gikandi et al., 2011). 
Taking into consideration the importance of formative assessment and the use of information and communications technology in higher education, this paper will show the options that the implementation of the Moodle platform provides for online student self-assessment by means of tests and quizzes as part of the preparation and simulation of the entrance exam for the Faculty of Economics of the University of Niš. With the aim of pointing out the potential of each of these types of assessment, in the second part of the paper we present an overview of the developmental phases of ICT in higher education, both from the aspect of their implementation in education, and from the aspect of their implementation in this study. The use of the Moodle platform in this particular case is described in the third part of the paper, while a statistical analysis of the test results of potential students is outlined in the fourth part of the paper. The advantages, drawbacks and potential directions of development of e-assessment at the Faculty of Economics of the University of Niš are presented in the conclusion of this paper.

\section{The Development and Application of e-Learning and e-Assessment in Higher Education}

Contemporary directions in the development of higher education inevitably include the implementation of ICTs. Activities such as e-learning and technology-enhanced learning - TEL have become an obligatory part of each higher education system, and provide new options and approaches to teaching, learning and assessment (Stödberg, 2012). However, technology-enhanced learning and assessment have developed over several phases, and the achieved extent of implementation to a great extent influences the results of the implementation of ICT in higher education.

If we were to view the development of e-learning, we could note different interpretations of this concept. The first interpretation of e-learning is the simplest one - it represents a part of the continuum of teaching, where at its beginning we find classic teaching methods and on the opposite end we find distance learning (Atkins \& Brown, 2002). Since we are operating within this range, technology is replacing classical forms of teaching more and more. In the beginning, technology had only a small influence on the way teaching was organised, since it was primarily used as help the classical teaching methods. The closer we are in this range to distance learning, the more technology influences the nature and organization of learning.

In the middle section of the range the authors find a combined model of teaching, where a significant portion of teaching in the classroom has been replaced by online teaching (note: mixed-mode, blended or hybrid learning). Since technology is being used in teaching and learning more and more, classical teaching methods are being used less and less, so that at the right-hand side of the 
continuum, classical methods no longer exist. Teaching has become fully online, and takes place with the help of technology.

This interpretation helps us understand the relations between distance learning and e-learning. Distance learning is becoming increasingly more online in nature, but historically speaking, other technologies have been used as well. Namely, there is a kind of distance learning which uses printed material and television, but it is not considered to be e-learning.

The second interpretation of e-learning was provided by the authors Bonk \& Dennen (1999), who described ten different levels of web integration into the classroom. These ten levels are divided into three groups: levels 1-5 denote the informational use of the web in education; levels 6-7 include the use of the web as an addition to teaching activities; while at levels 8-10 the Web plays a central role in the education process:

1. The Web is used for promoting courses and programs, or for publishing curricula and programs,

2. Research of resources available on the Web by the students,

3. Teachers publish the resources their students have developed (for example, well-written student papers),

4. Course resources can be found on the Web (for example, PowerPoint presentations, a list of the suggested reading material, exam questions) and students need to have access to them within a certain course,

5. Web resources which can be used multiple times - using material which is available online (for example, case studies),

6. Significantly increased use of the Web and assessment of activities in programs in which use of the Web has a great influence on the experiences which the students attending the course will gain (for example, using online discussions, online tests, forums),

7. Program activities take place outside of the teaching process itself - at this level of integration the Web is used as support for interaction and communication which include other students and teachers,

8. The Web as an alternative means of teaching students who require greater flexibility and more options for access to the classes, except for the classical approach to teaching,

9. The program completely takes place online, and is meant for students working or located in remote geographic locations, so as to enable students to attend lectures without physically being present, 
10. The course or program is a part of a broader initiative for the use of the Web in teaching.

Unlike the first interpretation, this division does not distinguish between various ways of using technology, in accordance with to how the class is being taught - in the classroom, in a combined manner or online.

The third interpretation of e-learning was put forth by the authors Zemsky \& Massy (2004) who through a market approach to e-learning divided it into three categories:

- E-learning as distance learning,

- E-learning as software meant to help teaching and learning and

- E-learning as electronically mediated learning.

Since it influences the quality of teaching and learning, assessment represents an essential component of effective learning and teaching (Bransford et al., 2000; Ferrari et al., 2009). Often it determines the priorities in education (NACCCE, 1999), but it always influences the work of teachers and the effects of learning (Cox \& Marshall, 2007). Changes in the curricula and goals of learning are ineffective if the assessment practices remain unchanged (Ferrari et al., 2009), considering that the learning and teaching models are formed in relation to the test (NACCCE, 1999).

The development of ICT and assessment tools has enabled the recognition of new knowledge and skills. Assessment through the implementation of ICT is also referred to as e-assessment, and this concept includes the overall process of assessment - from designing the questions and tasks to storing results with the help of ICT (Joint Information Systems Committee, 2007).

The processes of learning and assessment are influenced by a variety of technologies. Various studies have shown that there are numerous technologies available (Gartner, 2013). Some of them have been developed directly for teaching purposes, while most have been taken from e-commerce and adapted to the specific nature of the teaching process. The technologies which are used in education or will be implemented in the near future have great potential for implementation in assessment. Experience from practice indicates that e-assessment in education is currently at a crossroads between two paradigms - traditional computer testing and embedded assessment.

At the end of the 1980's Bunderson et al. (1989) predicted the following four generations of computer assistance in assessment:

- Generation 1: Computer testing (performing regular tests on a computer), 
- Generation 2: Computer adapted testing (adapting the level of difficulty of the test questions and the available response time based on previous answers),

- Generation 3: Continued measuring (the application of appropriate measures to continually predict dynamic changes student success) and

- Generation 4: Intelligent measuring (intelligent evaluation of the results, interpretation of individual student profiles, as well as recommendations for the teachers and students based on existing databases and prediction procedures).

Figure 1. shows the current and future e-assessment strategies.

Figure 1. Current and future e-Assessment strategies

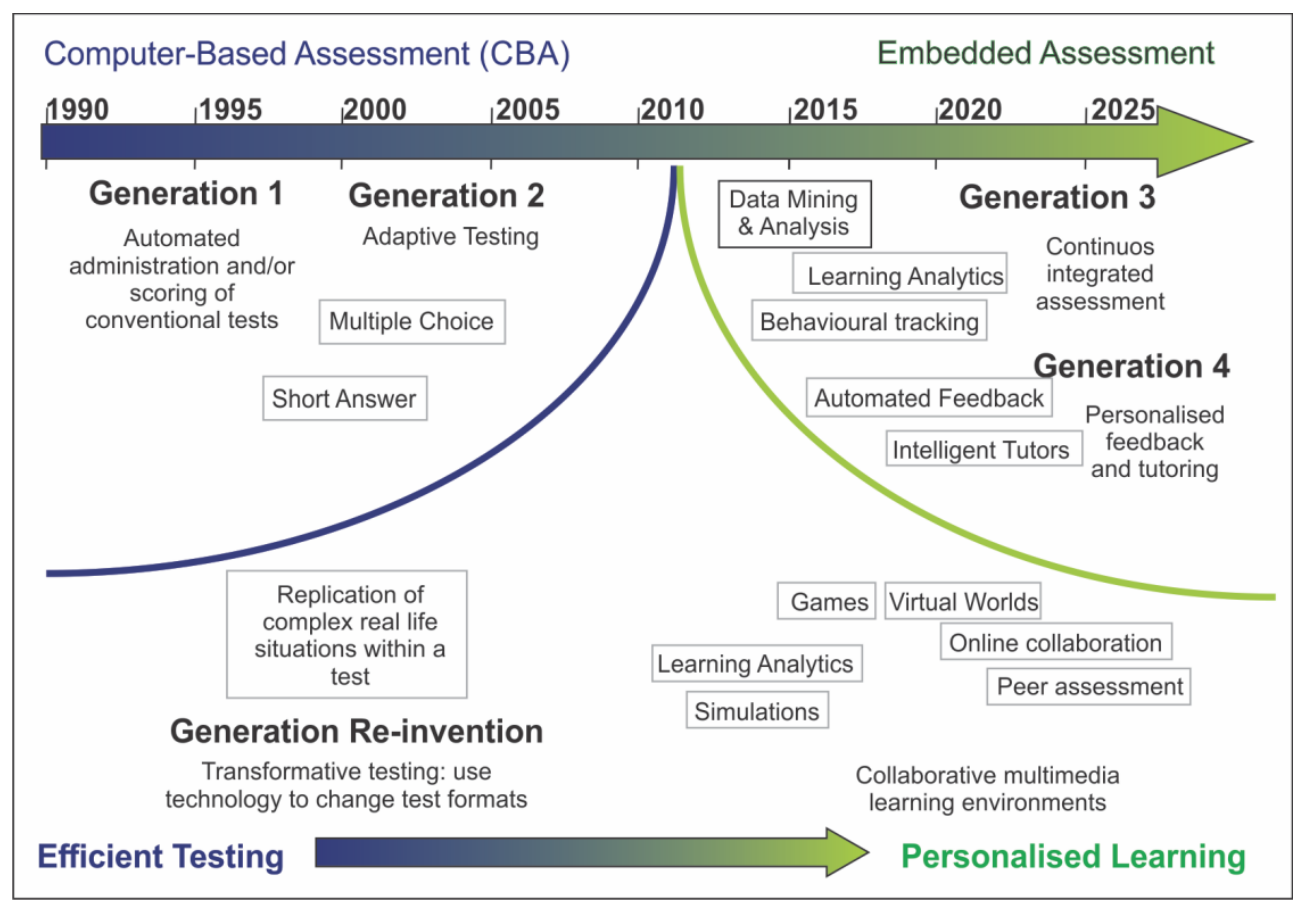

Source: Redecker \& Johannessen, 2013

This prediction is still current. The first two generations which can jointly be referred to as Computer-Based Testing today represent the main direction in the implementation of e-assessment. They are focused on testing and the implementation of computers to increase the effectiveness of the testing. Unlike computer-based testing, generations 3 and 4, which represent the phases of the development in embedded assessment, also integrate personalized assessment into the learning process. They enable the continued supervision of students and their 
guidance through the process of learning, combining formative and final assessment with the learning process. It is expected that the systems of the fourth generation will be able to offer immediate responses and reactions, and thus will be able to advise students and teachers regarding future learning strategies based on the individual needs and preferences of the students.

The transition from computer-based testing towards embedded assessment, which is based on the implementation of Learning Analytics, requires that the technological progress be accompanied by conceptual changes in the assessment itself. Learning analytics use data on the students' success for the assessment of academic progress, predicting future results and adapting education to suit the needs of individual students. It is expected that the learning analytics technique will have a broad implementation in the upcoming years (Johnson et al., 2011).

The cited paradigms of e-assessment, the Explicit Testing Paradigm, and the Embedded Assessment Paradigm are developed in parallel fashion to adapt to the more complex process of assessment which would be more suitable to for modern knowledge and skills and the pedagogical shift from learning which focuses on knowledge to learning which focuses on skills (Eurydice, 2012).

Formative assessment refers to assessment whose aim is to provide feedback on success in learning, to improve and quicken the learning process (Sadler, 1998). The main argument is that in higher education formative assessment and feedback could enable self-regulated learners. Self-regulation refers to the extent to which students actively monitor and regulate their train of thought, motivation and behaviour during the learning process (Pintrich \& Zusho, 2002). It includes the establishment of the goals in learning, strategies for the realisation of these goals, managing of resources and invested effort, as well as feedback from the environment. Feedback indicates the current relationship between the process of learning and the set goals. A student generates internal feedback by monitoring the results of his/her learning and the established goals, while external feedback is obtained from the professors or other students. That is why formative assessment could be considered the basic element in the process of contemporary education, since it provides students with regular and significant feedback on their acquired knowledge, and the teachers with information on the students, their way of learning and progress based on which they can further guide the learning process (Redecker \& Johannessen, 2013).

Pachler et al. (2010) propose 7 principles of good practice in connection with the development of self-regulated learners, which define success, the development of self-assessment, offer proper information to students regarding their learning, encourage dialogue with teachers and other students, increase motivation and selfconfidence, offer the possibility for overcoming differences between current and desired results and offer information to teachers on how to improve the learning process. 


\section{Implementation of the Moodle Platform for Student Self-Assessment}

Moodle as a very complex platform offers an array of functionalities from which the authors single out (Rice, 2015):

- The publication and exchange of teaching material (texts, images, multimedia presentations), with controlled access to this content.

- Online forums and discussions - provide interaction between the participants in the teaching process (both teachers and students) by implementing techniques such as chatting, forums and online discussions.

- Tests - a system of test and quiz design, with automatic assessment. The teachers can gain access to various statistics related to student responses and to feedback regarding where the students need further explanations, additional material.

- Collecting and reviewing student papers (term papers, case studies and other material which represents the result of student activity within the teaching process).

- Assessment - monitoring student activities through points acquired in individual segments of the course, which is very significant both for the students themselves and the teachers. The system provides each student with access to their own grades on tests and quizzes, providing at the same time user privacy.

- Additional functionalities of the Moodle - blogs, compiling glossaries, creating a Wiki system, etc.

The goal behind implementing the Moodle platform at the Faculty of Economics of the University of Niš is to provide support for future students who are preparing for the entrance exam. The aim is to offer candidates an environment in which they can check and self-assess their knowledge by simulating an entrance exam. A Moodle platform was installed, on which quizzes were designed for each of the four subjects which the candidates are tested on as part of the entrance exam (Business economics, Elements of Economics, Mathematics and Sociology). A web-based system was designed for self-assessment which could be accessed from the address (http://e-ucenje.eknfak.ni.ac.rs/moodle/). The webpage layout can be seen in Figure 2.

The goal behind the system was not the realisation of the entrance exam, but only a simulation which would include an appropriate bank of questions made up of questions taken from previous entrance exams. The candidate can create his/her own account and can monitor his/her progress. If he does not wish to do so, he/she can use the universal account to assess his/her own level of knowledge. 
Figure 2. Layout of the web page

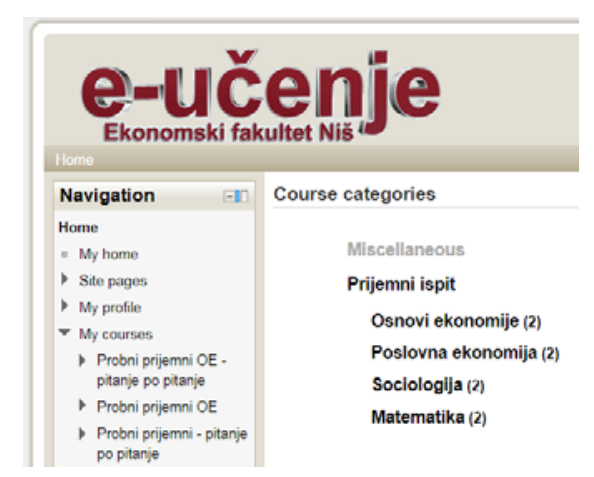

Source: The web page of the realised Moodle system

Once the candidate logs onto the system, he can select the desired course. Four courses were created to match the four subjects candidates would be tested on as part of their entrance exam. For each subject the candidate selects one of two options: individual questions that he is supposed to respond to, and immediately receive an assessment of his/her response (type 1), or a simulation of the entrance exam with a greater number of questions where only after the completed attempt (once an answer has been provided for all the questions) does the candidate get a final assessment for every individual question, as well as an overall grade, as is the case on the entrance exam (type 2).

The Moodle platform offers flexible tools for the design of quizzes. The Quiz Module is one of the most complex parts of the platform. Over years of development, numerous options and tools have been added. Support has been provided for the quick and simple design, publication and evaluation of quizzes. Further support has been offered for many types of questions, and it is possible to generate a quiz by a random selection of questions from an extensive question bank, which provides students with the option of retaking one of the quizzes, with the addition of quick assessment and detailed reports on the success of a given attempt. Feedback on achieved success is a critical element in the e-learning environment, and assessment is one of the most important activities in education. Only a well-designed test can provide good information on the students' knowledge, and enables the students themselves to follow their progress and thus help them achieve greater success (Cole \& Foster, 2007).

Quizzes can have multiple applications, which include (Rice, 2015):

- A short quiz after each lesson helps continued assessment during the school year. It is possible to include a random sequence of the questions to avoid cheating. It is also possible to limit access to a certain period of time when students are expected to learn the assigned lessons. 
- The quiz is often used as a trial test. It is possible to provide one or several attempts, or allow several tries until the correct answer has been provided.

- The quiz can also be used as a test to evaluate student knowledge prior to their attending a particular course. A comparison of the quiz results after the course has been completed can offer insight into a student's progress.

As the basis for the design of a quiz the authors use a question bank which represents a group of questions which can be used within a particular quiz. The questions in the bank can be grouped into categories. They can be shared, or used, in several courses or quizzes. The question bank which is formed over time represents the true value of the platform for learning and assessment.

A quiz is made up of a combination of settings regarding the appearance and completion of the quiz, the pages on which the quiz is displayed, and the questions which represent the content of the quiz. Adjustments to the quiz will define the number of questions on each page of the quiz, whether the student will access the given quiz once or several times, the time available to complete the quiz, etc. Each quiz can be made to be constantly available or available only for a previously determined period of time. The duration of the quiz can be limited, as is the case with standard tests, so that after the expiration of a particular period of time further work on the quiz is rendered impossible. If several attempts are allowed, it is possible to limit their number, and assessment can be defined that take into consideration the maximum, average, initial or final grade.

An important element of the quiz is also the sequence of the questions. It is possible to alter the questions so that they are presented in the order in which they were added to the quiz. However, the random order of questions is used more often, so that for each attempt the order is different, which makes responding more difficult. Navigating among the questions defines whether the student can go through the questions back and forth, whether he can return for the previous questions, or whether the questions must be answered sequentially, following the order in which they were given. Useful settings also include a random order of the offered responses to multiple choice questions.

For additional control of test performance the authors use adaptive modes, where the user is allowed several attempts to answer a specific question. Thus, the question is repeated several times, but for each incorrect response the candidate receives negative marks. If the number of negative points is $33.33 \%$ that means that the user has the right to 3 attempts. If he gets the answer right on the first attempt, he receives $100 \%$ of the points, on the second attempt $67 \%$, and on the third attempt only 33\% points.

By adjusting the option Feedback it is possible to define whether the student will answer the questions one at a time, or submit his/her answers to the quiz as a whole. If the user selects one question at a time, after answering each question the 
system informs him of whether his/her response is correct. If the deferred feedback option is selected, the student submits the entire test, and then obtains a complete report on the accuracy of the responses to each individual question.

Once the quiz is completed, the student is provided with a suitable report which consists of elements such as the offered responses, the selected response, feedback for each offered answer, the number of points for each individual question, as well as the overall achieved number of points for the complete quiz.

To provide greater quiz reliability, if it is being used to assess students, it is necessary to provide mechanisms which will decrease the possibility of abuse and cheating. The recommendation is that a question bank should be created, that the quiz should consist of a small number of questions, that the questions and answers should be provided in random order, that the quiz should be available only for a certain period of time, and that each question should be located on a separate page.

The question bank represents a group of all the questions which have been added to a Moodle site. It is possible to group the questions into suitable categories, such as those based on the subject matter they refer to. On the set-up website, there are 4 categories of questions, and a separate category for each course. Each question is characterized by a series of elements such as the type of the question, the name of the question, the text of the question - what is being shown to the student, the message that accompanies the response to the question, the offered answers and the message for each of the responses. The Moodle platform offers a complex question editor which supports various types of questions such as (Rice, 2015):

- Calculated questions - introduce a formula which is displayed as a part of the text of the question, containing parts that are filled in with random values during quiz completion,

- Calculated multichoice - introduce a formula and a list of offered values, so the student chooses one of them,

- Essay - free input of text as an answer to a question, but where it is not possible to automatically generate a response,

- Matching - a series of follow-up questions and answers are generated for the question, so the student needs to match the follow-up question and the response to it,

- Embedded answers - a text into which the participant embeds responses, while choosing between multiple-choice answers and fill-in-the-blanks or entering a numeric value,

- Multiple choice - the selection of one or more values, where each response is assigned a percentage of the overall number of points for that question. 
If only one response is selected, the correct response carries all the points, while the incorrect ones carry zero or negative points. If there is a multiple choice option then each of the alternatives carries an appropriate number of points, and incorrect responses zero or negative points. If a student correctly adds up all the alternatives, he/she gets $100 \%$ of the overall number of points; otherwise he merely gets a proportion,

- Short answers - the student provides a word or phrase for an empty slot,

- Numeric values - the participant enters a specific numeric value, and it is possible to define the tolerance within which the response is accepted,

- $\quad$ True/false - the student chooses whether a claim is true or false.

Once the necessary questions are generated within the question bank, it is possible to design the quiz by adding questions from the bank. For the quiz the authors define the overall number of points, while the number of points for each question is obtained by dividing the number of points on the quiz and the overall number of questions in it. If the correct order of questions in the quiz is required, the order is altered based on order of presentation, by moving the questions before or after some other question.

A question bank was created for the website used to simulate the entrance exam, where the questions were grouped into four categories corresponding to the four subjects. To the question bank the authors added questions from previous entrance exams, that is, questions from appropriate textbooks that students use to prepare for the entrance exam.

Two quizzes were designed for each subject, one consisting of one question after another, where the correct response is shown after each question (type 1), and one where the correct response for each question is displayed only after the quiz is completed (type 2).

Considering that the aim of the website is to help students prepare for the entrance exam, the time limit for which the test is made available was not fixed, nor was the number of attempts or the duration of each attempt. The participant was allowed to repeat the quiz as many times as he liked, and to return to any of the previous questions (for type 2), without any time limits. It was also possible to continue with a previous attempt if it was not completed. The overall grade of the participant was the grade given on the best attempt, where all the other scores were stored in case the participant made several attempts to complete the quiz. 


\section{Figure 3. The various types of questions}

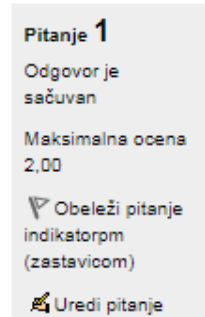

Kamata je:

Izaberite jedan odgovor:

a. dohodak vlasnika zajmovnog kapitala

b. dohodak od rada

c. dohodak vlasnika akcije

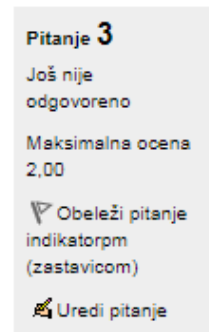

Navedite različita objašnjenja profita.

Izaberite jedan ili više odgovora:

$\square$ a. profit kao rezultat rada samog kapitaliste

$\square$ b. profit kao rezultat produktivnosti kapitala kao faktora proizvodnje

c. profit kao rezultat uzdržavanja od potrošnje (teorija apstinencije)

$\square$ d. profit kao nagrada za rizik i preduzetništvo

\section{Pitanje 4 \\ Još nije \\ odgovoreno \\ Maksimains ocens \\ 2,00}

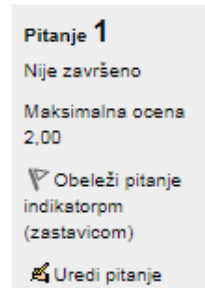

Kako se izračunava kamatna stopa?

Odgovor:

Rešiti iracionalnu nejednačinu $x-\sqrt{(x+2)(x-7)}=4$.

Izaberite jedan odgovor:

a. $x=10$

b. $x=11$

c. $x=7$

Source: Certain questions from the realised Moodle platform

\section{Methodology and Research Results}

The analysed data contains information from the Moodle database, including quiz results, the number of attempts, and correct and incorrect answers. The database contains data from the past three years, from 2014 to 2016. For each attempt at solving the quiz a LOG file records data on the user, the selected quiz, the duration of the attempt, the questions generated in the quiz, the responses and scores for each question. The Modul Grader report provides reports on the grades, and also 
offers detailed reports based on the participant, subject, quiz, etc. This data could be collected and analysed with various tools of statistical analysis or tools for learning analytics.

The entrance exam candidates can independently crate an account on the Moodle platform. Since the aim of the platform is the offer help in terms of selfassessment and preparation for the entrance exam, and not strict control, users are not required to include personal data, so they can protect their privacy. The user can also use a general student account, but he then loses the option of monitoring his/her progress, since multiple candidates can use the same account.

Figure 4 shows the number of newly-formed user accounts for each of the cited years. It can be noted that with the approach of the day of the official entrance exam (the end of June), the number of newly-formed accounts increased. Table 1 offers an overview of the overall number of candidates taking the entrance exam and the number of created Moodle accounts per year. In 2014 when the platform was launched, the possibilities for application were promoted on the social media, so that the number of created accounts was $50 \%$ greater than the number of candidates who applied.

Table 1. The number of candidates and created accounts

\begin{tabular}{|c|c|c|}
\hline & $\begin{array}{c}\text { Number of candidates taking the } \\
\text { entrance exam }\end{array}$ & $\begin{array}{c}\text { Number of created Moodle } \\
\text { accounts }\end{array}$ \\
\hline 2014 & 504 & 268 \\
\hline 2015 & 450 & 199 \\
\hline 2016 & 441 & 105 \\
\hline
\end{tabular}

Source: Author's analysis based on the data from the Moodle system

Figure 4. Accounts opened per day

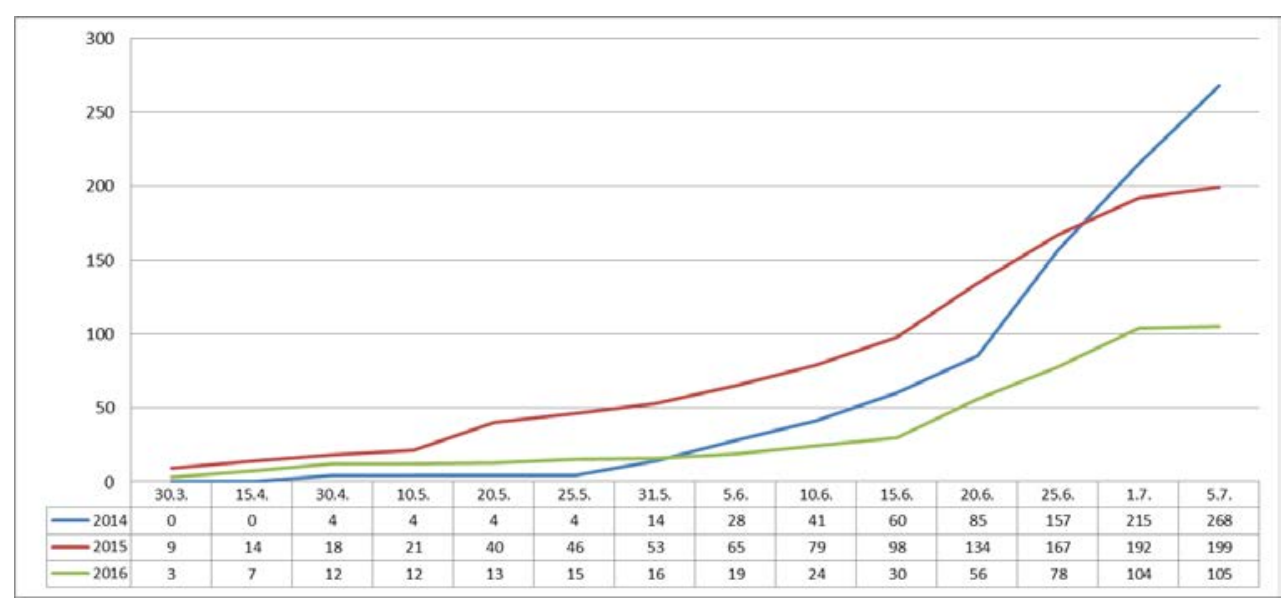

Source: Author's analysis based on the data from the Moodle system 
By analysing the data stored in the LOG files the number of times the site was visited each day can be isolated. The system was set up in 2014, at the very beginning of June, which is why the creation of accounts and number of visits increased at this time. Most of the visits can be link to the notices on Facebook, when 3000 visits were noted in a single day. Figure 5 indicates that the number of visits significantly increased during the month of June, and most of the visits were logged in the days immediately prior to the official entrance exam.

Figure 5. Overview of the visits per day for the period from 2014 to 2016

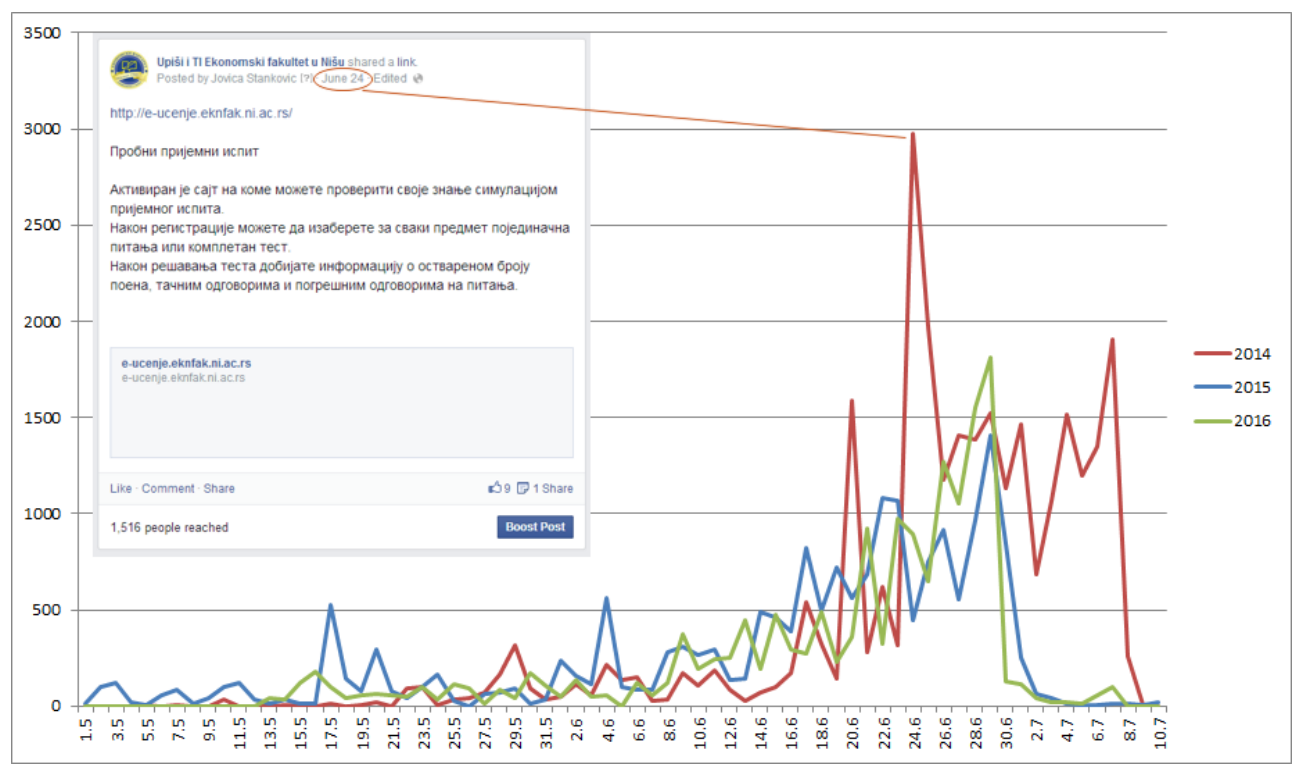

Source: Author's analysis based on the data from the Moodle system

Since the entrance exam usually takes place at the end of June, most of the accounts were created at the beginning of March, and a significant number of visits were recorded in May. During second time enrolment there was far less interest for preparing for the entrance exam, so these data are not relevant for analysis.

Data on the users of the Moodle platform for the simulation of the entrance exam and the results they achieved during the testing period from 2014 to 2016 are the basis for statistical analysis, which was used to determine the importance of formative assessment for effectiveness of learning.

During the studied period, most of the users, but also the best scores on the tests, presented in the form of correct responses, were noted in 2014 (Table 2). The trend of increased interest in certain subjects - Sociology and Business economics, can be seen during the entire studied period. Since the users were offered a choice between two types of testing, analyses were carried out for each type individually. Type 2 testing was a more frequent choice in 2014 and 2015, and at this time the 
candidates showed greater effectiveness of learning for all four subjects. However, in 2016 type 1 testing in Sociology and Elements of Economics proved to be more effective if the average grades are taken into consideration. Thus the $t$-test was used to test the hypothesis of the significance of formative assessment for more effective learning for each type of testing, by analysing the changes in the scores obtained during the first testing and in the highest recorded scores during testing for each individual subject.

Since the number of candidates who had applied for testing in Mathematics was very small, the testing results for this course were not analysed further.

Table 2. The number of users and the average grade per subject

\begin{tabular}{|l|l|l|l|l|l|l|l|l|l|}
\hline \multirow{2}{*}{ Year } & \multirow{2}{*}{$\begin{array}{c}\text { Type of } \\
\text { test }\end{array}$} & \multicolumn{2}{|c|}{ Sociology } & \multicolumn{2}{c|}{$\begin{array}{c}\text { Elements of } \\
\text { Economics }\end{array}$} & \multicolumn{2}{c|}{$\begin{array}{c}\text { Business } \\
\text { economics }\end{array}$} & \multicolumn{2}{c|}{ Mathematics } \\
\cline { 3 - 11 } & & $\mathrm{N}$ & $M$ & $\mathrm{~N}$ & $M$ & $\mathrm{~N}$ & $M$ & $\mathrm{~N}$ & $M$ \\
\hline \multirow{2}{*}{2014} & Type 1 & 37 & $48.71 \%$ & 11 & $59.13 \%$ & 58 & $52.52 \%$ & 2 & $51.30 \%$ \\
\cline { 2 - 11 } & Type 2 & 65 & $53.47 \%$ & 18 & $70.03 \%$ & 69 & $52.83 \%$ & 2 & $72.22 \%$ \\
\hline \multirow{2}{*}{2015} & Type 1 & 32 & $50.36 \%$ & 9 & $57.73 \%$ & 34 & $50.74 \%$ & 0 & - \\
\cline { 2 - 11 } & Type 2 & 52 & $52.67 \%$ & 9 & $69.11 \%$ & 51 & $52.57 \%$ & 2 & $91.11 \%$ \\
\hline \multirow{2}{*}{2016} & Type 1 & 12 & $53.23 \%$ & 7 & $63.25 \%$ & 16 & $50.77 \%$ & 1 & $63.50 \%$ \\
\cline { 2 - 10 } & Type 2 & 16 & $42.46 \%$ & 5 & $62.02 \%$ & 20 & $52.14 \%$ & 0 & - \\
\hline
\end{tabular}

Source: Author's analysis based on the data from the Moodle system

The results of the candidates who chose testing type 1 are shown in Table 3 . During testing in Sociology, 18 candidates, who selected this type of testing in the studied period, realised a significant increase in their final score of $37.30 \%$ compared to their first attempt $(t=-6.56, \mathrm{DF}=17, \mathrm{p}=0.000)$. In $50.00 \%$ of the cases the candidates made significant progress in learning after the second attempt at solving the Sociology test. The recorded results for the test on Elements of Economics which was taken by 11 candidates over the three-year period indicates a statistically significant increase in learning efficiency which resulted in a maximum score which was $51.97 \%$ greater compared to the first attempt $(t=-5.49, \mathrm{DF}=10$, $\mathrm{p}=0.000$ ). At that time, in $72.73 \%$ of the cases the progress in learning was clear after the first repeated test on Elements of Economics. The obtained results from Business economics in this kind of testing indicate a smaller learning effectiveness in comparison to the previous one, since the greatest logged score increased by $15.15 \%$ compared to the score obtained during the first testing attempt. However, these results could be considered statistically significant $(t=-4.09, \mathrm{DF}=23, \mathrm{p}$ $=0.000$ ). In $70.83 \%$ of the cases, progress was noted after the second attempt at solving the Business economics test. 
Table 3. The results of the paired $t$-test of the candidate's scores on the simulated entrance exam for type 1 testing

\begin{tabular}{|c|c|c|c|c|c|c|}
\hline Subject & Type 1 testing & $M$ & $S D$ & $t$ & $D f$ & $P$ \\
\hline \multirow{2}{*}{ Sociology } & First attempt & $41.72 \%$ & 0.016 & \multirow{2}{*}{-6.56} & \multirow{2}{*}{17} & \multirow{2}{*}{0.000} \\
\hline & Best attempt & $57.28 \%$ & 0.007 & & & \\
\hline \multirow{2}{*}{$\begin{array}{l}\text { Elements of } \\
\text { economics }\end{array}$} & First attempt & $53.09 \%$ & 0.039 & \multirow{2}{*}{-5.49} & \multirow{2}{*}{10} & \multirow{2}{*}{0.000} \\
\hline & Best attempt & $80.68 \%$ & 0.003 & & & \\
\hline \multirow{2}{*}{$\begin{array}{l}\text { Business } \\
\text { economics }\end{array}$} & First attempt & $50.62 \%$ & 0.013 & \multirow{2}{*}{-4.09} & \multirow{2}{*}{23} & \multirow{2}{*}{0.000} \\
\hline & Best attempt & $58.29 \%$ & 0.003 & & & \\
\hline
\end{tabular}

Source: Author's analysis based on the data from the Moodle system

Table 4 shows the test results of the candidates who selected type 2 testing during the entire studied period for the subjects Sociology, Business economics and Elements of Economics. The results of the paired-sample $t$-test indicate a strong statistically significant difference between the scores obtained during the first testing and the highest scores obtained during multiple attempts to complete the test. In the case of the Sociology test, during the studied period, this type of testing contributed the most to the increase in the scores of 59 candidates - the highest score was increased by $31.06 \%$ compared to the first score. This result can be considered statistically significant $(\mathrm{t}=-7.46, \mathrm{DF}=58, \mathrm{p}=0.000)$. This type of progress in $52.54 \%$ of the cases was realised after the first repeated test in Sociology. Progress made in learning can also be seen in the tests in Business economics, where 60 candidates increased their effectiveness of learning by $26.67 \%$ in this way, which also represents a statistically significant change in comparison to the scores obtained on the first testing $(\mathrm{t}=-6.67, \mathrm{DF}=59, \mathrm{p}=$ 0.000 ). In $58.33 \%$ of the cases, this increase was realised during the second testing in Business economics. The same conclusion can be drawn for Elements of Economics: the scores of the candidates during the testing increased by $27.96 \%$ compared to the initial ones, and in $55.56 \%$ of the cases this change was already manifested during the second attempt at solving the test. Based on the results for the $t$-value, it can be considered significant $(\mathrm{t}=-4.02, \mathrm{DF}=17, \mathrm{p}=0.000)$.

Table 4. The results of the paired $t$-test of the candidate's scores on the simulated entrance exam for type 2 testing

\begin{tabular}{|c|c|c|c|c|c|c|}
\hline Subject & Type 2 testing & $M$ & $S D$ & $t$ & $D f$ & $P$ \\
\hline \multirow{2}{*}{ Sociology } & First attempt & $45.26 \%$ & 0.022 & \multirow{2}{*}{-7.46} & \multirow{2}{*}{58} & \multirow{2}{*}{0.000} \\
\hline & Best attempt & $59.32 \%$ & 0.011 & & & \\
\hline \multirow{2}{*}{$\begin{array}{l}\text { Elements of } \\
\text { economics }\end{array}$} & First attempt & $58.22 \%$ & 0.053 & \multirow{2}{*}{-4.02} & \multirow{2}{*}{17} & \multirow{2}{*}{0.000} \\
\hline & Best attempt & $74.50 \%$ & 0.017 & & & \\
\hline \multirow{2}{*}{$\begin{array}{l}\text { Business } \\
\text { economics }\end{array}$} & First attempt & $47.40 \%$ & 0.023 & \multirow{2}{*}{-6.67} & \multirow{2}{*}{59} & \multirow{2}{*}{0.000} \\
\hline & Best attempt & $60.04 \%$ & 0.014 & & & \\
\hline
\end{tabular}

Source: Author's analysis based on the data from the Moodle system 
The obtained results indicate that the simulation of the entrance exam using the Moodle platform as a form of formative assessment can contribute to more effective learning and the realisation of better results of the candidates. However, the feedback available to the teachers can contribute to the better design of the test, in accordance with the needs of the students. For that purpose an analysis of the feedback was carried out using the following statistical indicators: the effective question weight index and the discrimination index (Rice, 2015).

The effective question weight indicates the influence of each individual question on the variance of the overall test result of the student and can be calculated using the following formula:

$$
E Q W I_{p}=100 \frac{\sqrt{C\left(x_{p}, T\right)}}{\sum_{p \in P} \sqrt{C\left(x_{p}, T\right)}}
$$

where $C\left(x_{p}, T\right)$ represents the covariance of the results for each question $p$ and the overall results achieved on test $T$.

The discrimination index represents the correlation between the achieved score on individual questions and the overall score on the test expressed in percentages. It can be calculated in the following way:

$$
D I_{i}=100 r\left(x_{i}, T\right)=100 \frac{C\left(x_{i}, T\right)}{\sqrt{V\left(x_{i}\right) V(T)}}
$$

where $V\left(x_{i}\right)$ and $V(T)$ represent result variances for each question and $i$ represents the overall result realised on test $T$.

The assumption which is the basis for the use of these indexes for the improvement of testing is that a well-formed question should prevent the existence of any differences between the predetermined question weight and the realised one, but that they should also contribute to testing success. Accordingly, it can be assumed that the correct answers to well-formed questions correlate with the overall test results among students who scored good test results.

Based on the results of these statistical indicators for each subject and each type of testing, shown in Figure 6, it can be concluded that there is a more or less pronounced oscillation in the values of these indexes. Greater oscillations can be noted for the values of both indexes, especially in the case of simulated entrance exams for subjects such as Sociology and Business economics, should be a signal to the teachers for the possible redefinition of questions, especially those where greater deviations are found. 
Figure 6. The effective weight index (a) and discrimination index (b) for each subject from 2014 to 2016
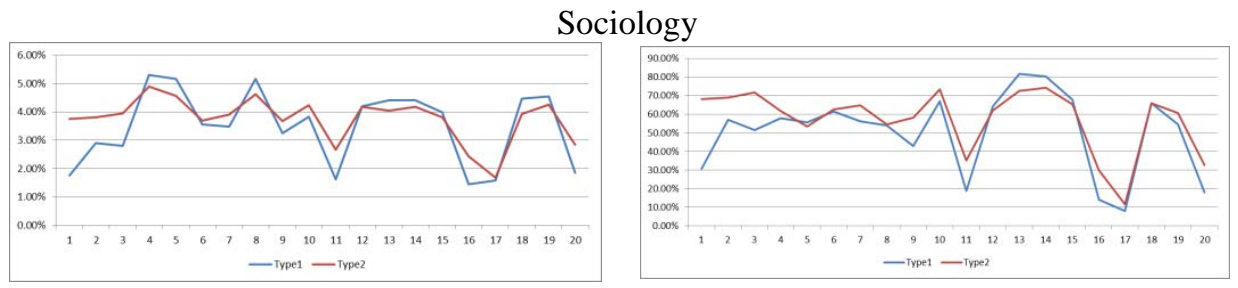

Business economics
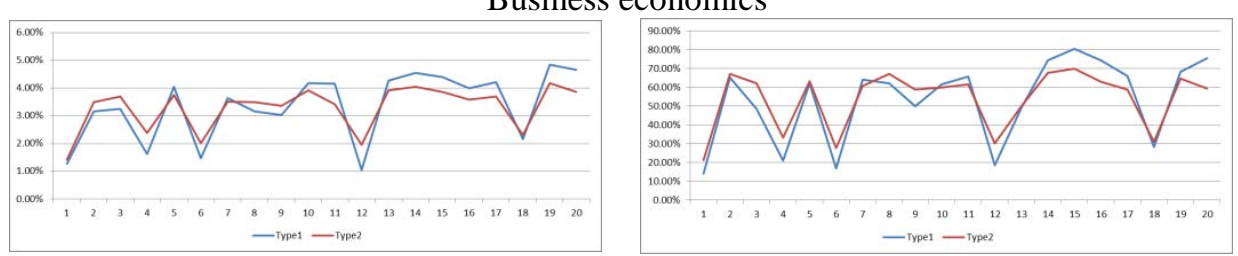

Elements of economics

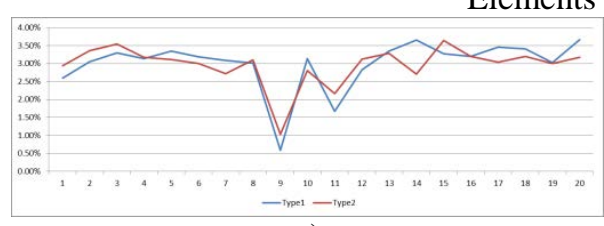

a)

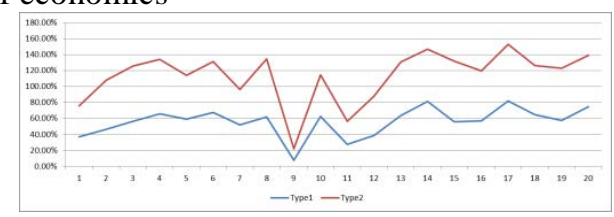

b)

Source: Author's analysis based on the data from the Moodle system

\section{Conclusion}

The intense use of tests in higher education contributes to great changes in the academic performance of the students. However, test-focused education is not effective unless the feedback is used to increase learning effectiveness. The implementation of the ICT in higher education significantly contributes to this goal, especially among self-regulated learners who decide themselves on the intensity and duration of the learning process. During that process formative assessment should offer guidelines for students and teachers alike regarding how they should adapt their work in order to realise the goals of the curriculum, while learning analytics should provide feedback for the students and teachers.

Despite all the advantages of e-learning and e-assessment, as well as the indicated level of student satisfaction when using the Moodle platform (Išljamović et al., 2012), in a certain number of higher education institutions in the Republic of Serbia they are still not being used. The main reasons for not using LMS include lack of staff education, lack of information on how such systems work and problems arising from course accreditation (Bulatović et al., 2013). 
In this particular case, based on the analysis of the number of visits and number of created accounts, it can be concluded that potential students have a tendency of using this type of testing, and the statistical analyses of the obtained results indicate that formative assessment significantly contributes to the increase in learning effectiveness. Taking into consideration the candidates' reaction to the information obtained from the social media on the possibilities of using the Moodle platform, insufficient use of the offered simulations of the entrance exam for the Faculty of Economics of the University of Niš can in part be a consequence of the lack of awareness on the part of the candidates on how this platform functions.

\section{References}

Atkins, M., \& Brown, G. (2002). Effective teaching in higher education. Routledge.

BäLter, O., EnströM, E., \& Klingenberg, B. (2013). The effect of short formative diagnostic web quizzes with minimal feedback. Computers \& Education, 60(1), 234-242.

Bonk, C. J., \& Dennen, V. (1999). Teaching on the Web: With a little help from my pedagogical friends. Journal of Computing in Higher Education, 11(1), 3-28.

Bransford, J. D., Brown, A. L., \& Cocking, R. R. (2000). How people learn - Brain, Mind, Experience, and School. National Academy Press, Washington, D.C.

Bulatović, N., Stefanović, D., Mirković, M., \& Ćulibrk, D. (2013). Primena sistema za elektronsko učenje na visokoškolskim ustanovama u Srbiji-pregled aktuelnog stanja. Infoteh - Jahorina, 12, 743-746.

Bull, J., \& Dalziel, J. (2003). Assessing question banks. Reusing Online Resources" edited Allison Littlejohn, Korgan Page, 171-181.

Bunderson C V, Inouye D K and Olsen J B (1989) The four generations of computerized educational measurement in R L Linn (ed) Educational measurement American Council on Education, Washington DC, 367-407.

Capterra, Top 20 Most Popular LMS Software, Retrieved from: http://www.capterra.com/learning-management-system-software/\#infographic, Accessed on Febraury 2017.

Cole, J., \& Foster, H. (2007). Using Moodle: Teaching with the popular open source course management system. " O'Reilly Media, Inc.".

Cox, M. J., \& Marshall, G. (2007). Effects of ICT: do we know what we should know?. Education and information technologies, 12(2), 59-70.

Ćukušić, M., Garača, Ž., \& Jadrić, M. (2014). Online self-assessment and students' success in higher education institutions. Computers \& Education, 72, 100-109.

Eurydice, Educational, Audiovisual, \& Culture Executive Agency. (2012). The european higher education area in 2012: Bologna process implantation report. Ministerio de Educación.

Ferrari, A., Cachia, R., \& Punie, Y. (2009). Innovation and creativity in education and training in the EU member states: Fostering creative learning and supporting innovative teaching. JRC Technical Note, 52374.

Garrison, C., \& Ehringhaus, M. (2007). Formative and summative assessments in the classroom. 
Gartner, Inc. (2013). Gartner’s hype cycle special report for 2013. Retrieved from http://my.gartner.com/portal/server.pt?showOriginalFeature=y\&open=512\&objID=260\&m ode=2\&PageID=3460702\&id=2574916\&ref=, Accessed on February 10, 2017

Gikandi, J. W., Morrow, D., \& Davis, N. E. (2011). Online formative assessment in higher education: A review of the literature. Computers \& education, 57(4), 2333-2351.

Išljamović, S., Vukićević, M., \& Suknović, M. Zadovoljstvo studenata pri korišćenju Moodle platforme za tehnološki podržano učenje.

Jenkins, M. (2005). Unfulfilled promise: formative assessment using computer-aided assessment. Learning and Teaching in Higher Education, (1), 67-80.

Johnson, L., Levine, A., Smith, R., \& Stone, S. (2010). The 2011 Horizon Report. The New Media Consortium. Austin, Texas.

Joint Information Systems Committee. (2007). Effective Practice with e-Assessment: An overview of technologies, policies and practice in further and higher education. Joint Information Systems Committee.

Kulkarni, C., Wei, K. P., Le, H., Chia, D., Papadopoulos, K., Cheng, J., ... \& Klemmer, S. R. (2015). Peer and self assessment in massive online classes. In Design thinking research (pp. 131-168). Springer International Publishing.

Lee, Y., \& Choi, J. (2011). A review of online course dropout research: Implications for practice and future research. Educational Technology Research and Development, 59(5), 593-618.

Milićević, V., Milićević, Z., \& Milić, N. (2014). Electronic learning in Serbia using Moodle software. Bizinfo (Blace), 5(1), 71-82.

NACCCE. (1999). All our futures: Creativity, culture and education.

Nicol, D. J., \& Macfarlane-Dick, D. (2006). Formative assessment and self-regulated learning: A model and seven principles of good feedback practice. Studies in higher education, 31(2), 199-218.

Pachler, N., Daly, C., Mor, Y., \& Mellar, H. (2010). Formative e-assessment: Practitioner cases. Computers \& Education, 54(3), 715-721.

Pintrich, P. R., \& Zusho, A. (2002). The development of academic self-regulation: The role of cognitive and motivational factors.

Pryor, J., \& Crossouard, B. (2010). Challenging formative assessment: disciplinary spaces and identities. Assessment \& Evaluation in Higher Education, 35(3), 265-276.

Redecker, C., \& Johannessen, Ø. (2013). Changing assessment-Towards a new assessment paradigm using ICT. European Journal of Education, 48(1), 79-96.

Rice, W. (2015). Moodle E-Learning Course Development. Packt Publishing Ltd.

Sadler, D. R. (1998). Formative assessment: Revisiting the territory. Assessment in education: principles, policy \& practice, 5(1), 77-84.

Stödberg, U. (2012). A research review of e-assessment. Assessment \& Evaluation in Higher Education, 37(5), 591-604.

Willems, J. (2011). Using learning styles data to inform e-learning design: A study comparing undergraduates, postgraduates and e-educators. Australasian Journal of Educational Technology, 27(6).

Zemsky, R. \& Massy, W. F. (2004). Thwarted Innovation What Happened to e-learning and Why, The Learning Alliance at the University of Pennsyvlania

Zorrilla, M., García, D., \& Álvarez, E. (2010, March). A decision support system to improve e-learning environments. In Proceedings of the 2010 EDBT/ICDT Workshops (p. 11). ACM. 


\section{PRIMENA MOODLE PLATFORME U ONLAJN SAMOEVALUACIJI STUDENATA}

Apstrakt: Uzevši u obzir značaj informaciono-komunikacionih tehnologija u visokom obrazovanju i to kako u nastavi, tako i u ocenjivanju, ali i ograničenja za primenu istih u visokom obrazovanju u Republici Srbiji, u ovom radu su prikazane mogućnosti koje pruža Moodle platforma za definisanje i korišćenje onlajn testova i kvizova za samoevaluaciju u pripremi i simulaciji prijemnog ispita za upis na Ekonomski fakultet Univerziteta u Nišu. U cilju isticanja značaja e-ocenjivanja za povećanje efektivnosti učenja, u radu je analiziran broj kreiranih korisnika i broj pristupa, dok je statističkom analizom ostvarenih rezultata kandidata na simulaciji prijemnog ispita u periodu od 2014. do 2016. godine testirana hipoteza o značaju formativnog ocenjivanja za efektivno učenje. Dobijeni rezultati $t$-testa ukazuju na činjenicu da formativno ocenjivanje u konkretnom slučaju doprinosi unapređenju učenja kandidata i da bi primena ovakvog načina samoevaluacije studenata u drugim sferama učenja značajno doprinela povećanju efektivnosti učenja. S druge strane, statističke analize pojedinačnih odgovora na pitanja predstavljaju značajan izvor povratnih informacija za nastavnike, koje se mogu koristiti u svrhu redefinisanja testova.

Ključne reči: Moodle platforma, formativno ocenjivanje, onlajn samoevaluacija, visoko obrazovanje.

\section{Authors' biographies}

Jovica Stanković graduated from the Faculty of Electronics at the University of Niš in 1996. He received his M.Sc. degree (2006) from the Faculty of Electronics at the University of Niš in the field of Computer Science and Informatics. He received his Ph.D. degree (2017) from the Faculty of Economics at the University of Niš. He is employed at the Faculty of Economics, University of Niš. He has published more than fifty scientific and professional papers, the university textbooks Business Informatics - Practical Approach and Business Information Systems (co-author). His fields of interests include information technology, information systems, data bases and data warehousing.

Slavoljub Milovanović is professor at the Faculty of Economics, University of Niš, Serbia. He obtained his Bachelor's Degree in field of economics from the Faculty of Economics at the University of Niš and completed his Master's study at the Faculty of Economics, University of Belgrade, Serbia. The profile of the study was: Information Systems and Cybernetics. He received his Ph.D. degree in the field of Management Information Systems from University of Niš. His research interests include strategic management and use of information systems (IS), knowledge management, electronic business and IS function 
transformation. He teaches Informatics, Business Information Systems and Electronic Business at the Faculty of Economics, University of Niš.

Ognjen Radović is Associate Professor at the Faculty of Economics, University of Niš, Serbia. He graduated from the Faculty of Electronics, University of Niš in 1992 and received his M.Sc. degree (2003) from the Faculty of Economics at the University of Niš. He received his Ph.D. degree (2011) from the Faculty of Economics in Subotica at the University of Novi Sad. He teaches Informatics, Business Information Systems and Electronic business at The Faculty of Economics, University of Niš. 